University of Nebraska - Lincoln

DigitalCommons@University of Nebraska - Lincoln

Faculty Publications: Department of Entomology

Entomology, Department of

1996

\title{
Population Genetics and Gene Variation in Screwworms (Diptera: Calliphoridae) from Brazil
}

\author{
David B. Taylor \\ University of Nebraska, Lincoln, dtaylor1@unl.edu \\ Richard D. Peterson II \\ University of Nebraska, Lincoln \\ Gonzalo E. Moya-Borja \\ Universidade Federal Rural do Rio de Janeiro
}

Follow this and additional works at: https://digitalcommons.unl.edu/entomologyfacpub

Part of the Entomology Commons

Taylor, David B.; Peterson, Richard D. Il; and Moya-Borja, Gonzalo E., "Population Genetics and Gene Variation in Screwworms (Diptera: Calliphoridae) from Brazil" (1996). Faculty Publications: Department of Entomology. 217.

https://digitalcommons.unl.edu/entomologyfacpub/217

This Article is brought to you for free and open access by the Entomology, Department of at DigitalCommons@University of Nebraska - Lincoln. It has been accepted for inclusion in Faculty Publications: Department of Entomology by an authorized administrator of DigitalCommons@University of Nebraska - Lincoln. 


\title{
Population Genetics and Gene Variation in Screwworms (Diptera: Calliphoridae) from Brazil
}

\author{
David B. Taylor, ${ }^{1,2}$ Richard D. Peterson, II, $^{1}$ and Gonzalo E. Moya-Borja ${ }^{3}$
}

Received 3 Oct. 1995-Final 20 Nov. 1995

Allozyme variation in New World screwworm, Cochliomyia hominivorax (Coquerel), populations from Brazil was examined. Variability was observed in 8 of 13 enzyme loci and the frequency of the most common allele was $<0.95$ for seven loci. Observed and expected heterozygosities were 0.159 and 0.165, respectively. Comparisons of the Brazilian populations with previously studied populations from Costa Rica resulted in Nei's genetic distances of between 0.000 and $0.006_{2}$ with the greatest distance being between populations within Brazil. Comparisons with Mexican populations using only three loci resulted in genetic distances $\leq 0.031$. Goodness-of-fit statistics for Hardy-Weinberg equilibrium and Wright's $\mathrm{F}$ statistics indicated small deviations from expected equilibrium genotype frequencies and low levels of differentiation between populations within Brazil. Differentiation among screwworm populations from Brazil, Costa Rica, and Mexico was minimal.

KEY WORDS: Cochliomyia hominivorax; population genetics; isozymes.

\section{INTRODUCTION}

The New World screwworm (NWS), Cochliomyia hominivorax (Coquerel), is a serious pest of livestock throughout the tropical and subtropical regions of South America (Guimaraes et al., 1983; Dear, 1985). Prior to its eradication from North America using the sterile insect technique (Graham, 1985),

\footnotetext{
${ }^{1}$ Midwest Livestock Insects Research Laboratory, USDA-ARS, Department of Entomology, University of Nebraska, Lincoln, Nebraska 68583.

${ }^{2}$ To whom correspondence should be addressed at USDA-ARS, Room 305, Plant Industry Building, East Campus, UNL, Lincoln, Nebraska 68583. Fax: (402) 432-5260.

${ }^{3}$ Universidade Federal Rural do Rio de Janeiro, Rio de Janeiro, Brazil.
}

0006-2928/96/0200-0067\$09.50/0 1996 Plenum Publishing Corporation 
NWS was distributed from the United States to Argentina (Dear, 1985) (Fig. 1). Eradication programs have eliminated this pest from the United States, Mexico, Guatemala, and Belize (Graham, 1985; Vargas-Teran, 1991). The goal of the eradication programs is to eradicate the species to the isthmus of Panama and maintain a permanent barrier at that point to prevent reinfestations of Central America from South America (Krafsur $e t$ al., 1987).

The sterile insect technique is dependent on the mating compatibility of the sterile released insects and the native target population (Knipling, 1955; Krafsur et al., 1987). Richardson et al. (1982) proposed that NWS was a complex of reproductively isolated populations in North America. Subsequent studies failed to find evidence of population substructuring (LaChance et al., 1982; McInnis, 1983; McInnis et al., 1983; Dev et al., 1986; Krafsur and Whitten, 1993; Taylor and Peterson, 1994) and NWS was successfully eradicated from North America in 1991 (Vargas-Terán, 1991). Unfortunately, none of these studies included NWS populations from South America. If reproductively isolated populations of NWS do exist, they will probably be found in South America, given the biogeographic history of the Americas (Stehli and Webb, 1985). Although no NWS eradication programs are currently planned for South America, knowledge of the species population structure in that region is important to the eradication and maintenance programs in Central America. When the sterile fly barrier is established at the Isthmus of Panama, it will be under constant pressure from South American NWS populations. Furthermore, the feasibility of eventually eradicating NWS from South America is dependent upon the reproductive compatibility of this species across its range.

The purpose of this study was to use allozymes to analyze genetic variability and population structure of NWS populations from South America and compare them with populations from Central America. Populations from southern Brazil were used because they are most distant from Central America and most likely to reflect differences which may be present between Central and South America.

\section{MATERIALS AND METHODS}

Specimens. Adult NWS were collected from the campus of the Universidade Federal Rural do Rio de Janeiro, Rio de Janeiro, Brazil, from 26 March to 21 April 1994. A calf with a naturally infested wound was used to attract NWS flies. NWS larvae were collected from wounded calves at the Universidade Federal Rural do Rio Grande do Sul and reared to adults from 3 to 28 March 1993. One adult was analyzed from each collection. Adults were stored in liquid nitrogen and transported to the USDA-ARS Midwest 


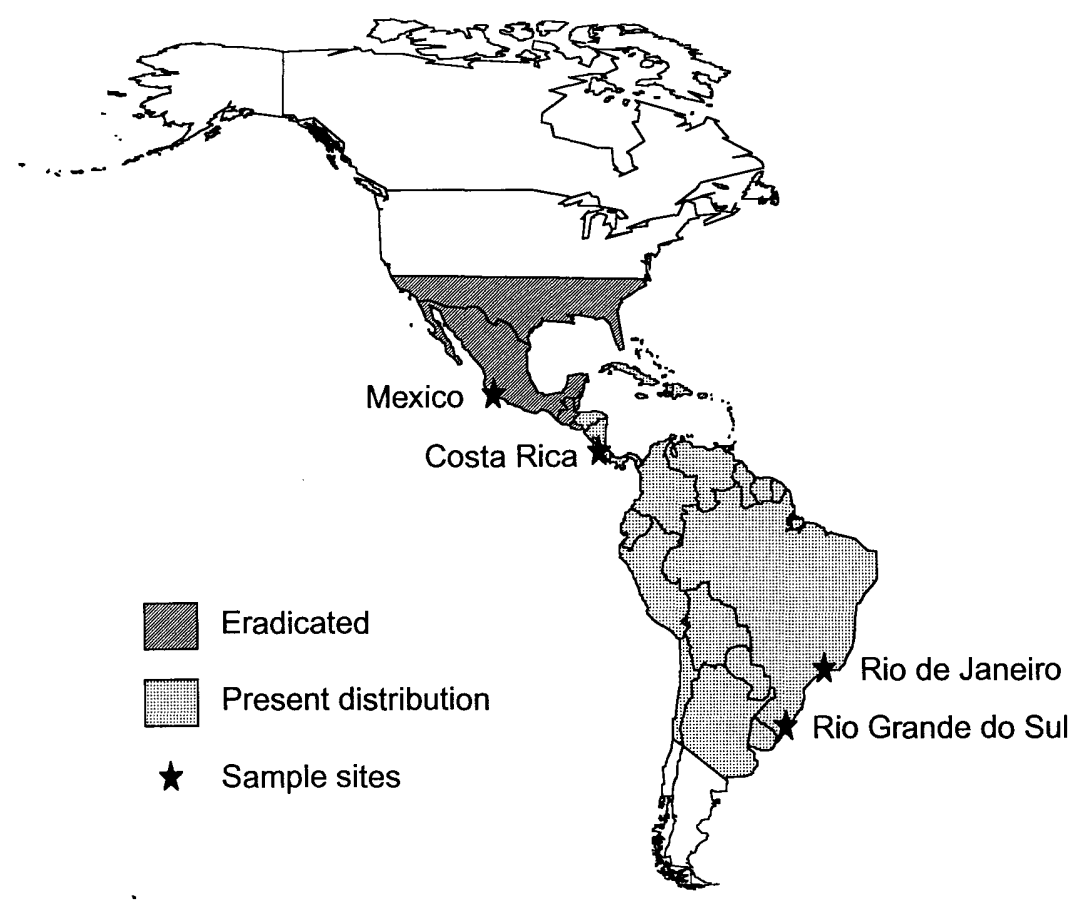

Fig. 1. Distribution of New World screwworm and sampling sites.

Livestock Insects Research Laboratory, Lincoln, Nebraska, where they were stored at $-80^{\circ} \mathrm{C}$. Seventy-three flies ( 72 females and 1 male) were analyzed from Rio de Janeiro and 50 flies ( 25 females and 25 males) were analyzed from Rio Grande do Sul.

Electrophoretic Techniques. Polyacrylamide gel electrophoresis was used for this study. Techniques were the same as those reported by Taylor and Peterson (1994). Heads were removed from each fly and stored individually for use in future molecular genetic studies. Decapitated flies were ground in $150 \mu$ l of grinding buffer [ $10 \%$ sucrose, $0.1 \%$ Triton X-100 (Sigma Chemical Co., St. Louis, MO), $0.37 \%$ EDTA, bromophenol blue, and mercaptoethanol in 1:5 diluted Tris-citrate, pH 7.1 (TC) buffer]. Electrophoresis conditions were $6 \%$ polyacrylamide gels $(14 \times 16 \mathrm{~cm}$ and $1.5 \mathrm{~mm}$ thick) run at $300-\mathrm{V}$ constant voltage for $3 \mathrm{hr}$ [Tris:borate:EDTA, pH 8.9 (TBE) buffer] or $4 \mathrm{hr}$ (TC buffer) using vertical slab gel units (Hoeffer Scientific, San Francisco, CA). Initial currents were 27 (TBE) and 45 (TC) mA per gel and ending currents were 15 (TBE) and 39 (TC) mA per gel. Buffer in the TC units was circulated between the upper and the lower chambers to avoid overheating. Staining procedures, recipes, and allele nomenclature were the 
same as those used by Taylor and Peterson (1994). Thirteen enzyme systems were used for this study (Table I).

Statistical Analysis. BIOSYS-1 (Swofford and Selander, 1981) was used to compute population allele frequencies and expected and observed heterozygosities, test for fit with Hardy-Weinberg expectations, and calculate Nei's (1978) genetic distance and Wright's (1978) $F$ statistics. Significant deviation from zero of Wright's $F_{\mathrm{ST}}$ and $F_{\text {IT }}$ statistics was determined by calculating $\chi^{2}$ statistics with the following formulas: $\chi^{2} F_{\mathrm{ST}}=2 N\left(F_{\mathrm{ST}}\right)(k-1)$ with $(k-1)(s-1)$ df and $\chi^{2} F_{\mathrm{IT}}=\left(F_{\mathrm{IT}}\right)^{2} N(k-1)$ with $k(k-1)$ df for $k$ alleles and $s$ populations. The $\chi^{2}$ contingency analysis with Yate's adjustment for small expected frequencies was used to compare allele frequencies among populations.

\section{RESULTS}

Eight of thirteen isozyme loci were variable and seven were polymorphic (frequency of most common allele, <0.95) (Table II). Expected and observed heterozygosities were 0.159 and 0.165 , respectively (Table I). Observed genotypes did not differ significantly from Hardy-Weinberg expectations [with pooling (see Swofford and Selander, 1981); $P<0.05$ ] except for

Table I. Gene Diversity at Enzyme Loci in C. hominivorax from Brazil

\begin{tabular}{|c|c|c|c|c|c|}
\hline Enzyme & EC No. ${ }^{a}$ & Symbol ${ }^{b}$ & No. alleles & $H_{\mathrm{O}}^{c}$ & $H_{\mathrm{E}}^{d}$ \\
\hline Aconitate hydratase & 4.2.1.3 & $\mathrm{ACOH}$ & 3 & 0.129 & 0.131 \\
\hline Formaldehyde dehydrogenase & 1.2.1.1 & FDH & 2 & 0.294 & 0.295 \\
\hline Fructose-biphosphate aldolase & 4.1.2.13 & ALD & 1 & 0.000 & 0.000 \\
\hline Fumarate hydratase & 4.2 .1 .2 & FUMH & 1 & 0.000 & 0.000 \\
\hline $\begin{array}{l}\text { Glyceraldehyde-3-phosphate } \\
\text { dehydrogenase }\end{array}$ & 1.2.1.12 & GAPDH & 1 & 0.000 & 0.000 \\
\hline Glycerol dehydrogenase & 1.1.1.72 & GCD & 2 & 0.212 & 0.213 \\
\hline $\begin{array}{l}\text { Glycerol-3-phosphate } \\
\text { dehydrogenase }\end{array}$ & 1.1.1.8 & G3PDH & 3 & 0.500 & 0.502 \\
\hline Hydroxyacid dehydrogenase & 1.1.99.6 & HADH & 2 & 0.468 & 0.470 \\
\hline Isocitrate dehydrogenase & 1.1.1.42 & IDH & 3 & 0.055 & 0.056 \\
\hline Malate dehydrogenase & 1.1.1.37 & MDH & 1 & 0.000 & 0.000 \\
\hline $\begin{array}{l}\text { Mannose-6-phosphate isomerase } \\
\text { Phosphogluconate }\end{array}$ & 5.3.1.8 & MPI & 6 & 0.333 & 0.334 \\
\hline & 1.1.1.44 & PGDH & 1 & 0.000 & 0.000 \\
\hline Phosphoglucomutase & 5.4 .2 .2 & PGM & 4 & 0.145 & 0.146 \\
\hline Mean \pm SE & & & \multicolumn{3}{|c|}{$2.31 \pm 0.410 .159 \pm 0.0500 .165 \pm 0.051$} \\
\hline
\end{tabular}

\footnotetext{
${ }^{a}$ Nomenclature Committee International Union of Biochemistry 1984.

${ }^{b}$ From Murphy et al. (1990).

${ }^{c}$ Observed heterozygosity.

${ }^{d}$ Expected heterozygosity based upon Hardy-Weinberg equilibrium.
} 
Table II. Allele Frequencies for Variable Isozyme Loci in C. hominivorax from Brazil and Costa Rica

\begin{tabular}{|c|c|c|c|}
\hline Locus allele & Costa Rica & Rio de Janeiro & Rio Grande do Sul \\
\hline$A \operatorname{coh}(n)^{a}$ & 287 & 49 & 9 \\
\hline 60 & 0.005 & 0 & 0.056 \\
\hline 80 & 0.012 & 0.071 & 0 \\
\hline 100 & 0.981 & 0.929 & 0.944 \\
\hline 112 & 0.002 & 0 & 0 \\
\hline$F d h(n)^{a}$ & 287 & 73 & 50 \\
\hline 66 & 0.014 & 0 & 0 \\
\hline 84 & 0.112 & 0.260 & 0.060 \\
\hline 100 & 0.874 & 0.740 & 0.940 \\
\hline Fumh $(n)^{a}$ & 287 & 73 & 50 \\
\hline 60 & 0.003 & 0 & 0 \\
\hline 100 & 0.997 & 1.000 & 1.000 \\
\hline $\operatorname{Gapdh}(n)^{a}$ & 287 & 73 & 50 \\
\hline 100 & 1.000 & 1.000 & 1.000 \\
\hline $\operatorname{Gcd}(n)^{a}$ & 287 & 73 & 47 \\
\hline 86 & 0.155 & 0.075 & 0.191 \\
\hline 100 & 0.841 & 0.925 & 0.809 \\
\hline 116 & 0.003 & 0 & 0 \\
\hline$G 3 p d h(n)^{a}$ & 287 & 73 & 50 \\
\hline 74 & 0.481 & 0.438 & 0.468 \\
\hline 85 & 0 & 0.007 & 0 \\
\hline 100 & 0.519 & 0.555 & 0.532 \\
\hline $\operatorname{Hadh}(n)^{a}$ & 287 & 73 & 50 \\
\hline 100 & 0.688 & 0.637 & 0.610 \\
\hline 115 & 0.242 & 0.363 & 0.390 \\
\hline 130 . & 0.070 & 0 & 0 \\
\hline $\operatorname{Idh}(n)^{a}$ & 287 & 73 & 50 \\
\hline 93 & 0 & 0 & 0.010 \\
\hline 100 & 0.997 & 0.959 & 0.990 \\
\hline 117 & 0.003 & 0 & 0 \\
\hline 129 & 0 & 0.041 & 0 \\
\hline $\operatorname{Mdh}(n)^{a}$ & 287 & 73 & 50 \\
\hline 73 & 0.003 & 0 & 0 \\
\hline 100 & 0.986 & 1.000 & 1.000 \\
\hline 130 & 0.009 & 0 & 0 \\
\hline 158 & 0.002 & 0 & 0 \\
\hline $\operatorname{Mpi}(n)^{a}$ & 287 & 73 & 49 \\
\hline 92 & 0.016 & 0 & 0 \\
\hline 100 & 0.791 & 0.740 & 0.908 \\
\hline 108 & 0.193 & 0.144 & 0.071 \\
\hline 112 & 0 & 0.075 & 0 \\
\hline 130 & 0 & 0.021 & 0 \\
\hline 134 & 0 & 0 & 0.020 \\
\hline 160 & 0 & 0.021 & 0 \\
\hline $\operatorname{Pgm}(n)^{a}$ & 287 & 73 & 50 \\
\hline 85 & 0 & 0.027 & 0 \\
\hline 91 & 0.005 & 0.014 & 0 \\
\hline 100 & 0.970 & 0.870 & 1.000 \\
\hline 108 & 0.024 & 0.089 & 0 \\
\hline $\operatorname{Pgdh}(n)^{a}$ & 287 & 73 & 50 \\
\hline 60 & 0.005 & 0 & 0 \\
\hline 100 & 0.995 & 1.000 & 1.000 \\
\hline
\end{tabular}

${ }^{a}$ Number of individuals interpreted from each population. 
Gcd in the Rio de Janeiro collection (excess homozygotes, $\chi^{2}=7.993$, $\mathrm{df}=1, P<0.005)$ and $G 3 p d h$ and Hadh in the Rio Grande do Sul collection (excess heterozygotes, $\chi^{2}=9.184, \mathrm{df}=1, P=0.002$, and excess homozygotes, $\chi^{2}=4.376, \mathrm{df}=1, P=0.036$, respectively).

Wright's $F$ statistics indicate little departure from random mating within NWS populations from Brazil (Table III). $F_{\text {IT }}$ was significantly positive for $H a d h$, however, the mean $F_{\mathrm{IS}}$ and $F_{\mathrm{IT}}$ values, -0.001 and 0.022 , respectively, were small. Both Hardy-Weinberg contingency $\chi^{2}$ and $F_{\text {ST }}$ values (Table III) indicated that allele frequencies were not homogeneous between the Brazilian populations.

Although significant differences in allele frequencies among populations from Brazil and Costa Rica (Taylor and Peterson, 1994) were observed, most of the variation was attributable to individuals within populations and populations within countries (Table IV). The hierarchical $F$ value for country within total was -0.001 . Likewise, hierarchical analysis including populations from Mexico (Krafsur and Whitten, 1993) for the three loci studied by those authors (Table V) indicated little differentiation among countries. Nei's unbiased genetic distances were $\leq 0.006$ (Table VI) for the comparisons within and between Brazil and Costa Rica based upon 13 loci. Genetic distances $\leq 0.031$ were observed in the comparisons with Mexico based upon three loci.

Cluster analyses based on Nei's and modified Roger's genetic distances and distance Wagner procedures (Swofford and Selander, 1981) using both the complete data set of 13 enzyme loci for Costa Rica and Brazil and the partial data set of 3 enzyme loci for Mexico, Costa Rica, and Brazil failed to segregate the Brazilian populations from the Costa Rican populations. In the latter analysis, the Mexican populations did cluster together.

Table III. Hardy-Weinberg Contingency $\chi^{2}$ and Wright (1978) $F$ statistics for Two C. hominivorax Populations from Brazil

\begin{tabular}{|c|c|c|c|c|c|}
\hline \multirow[b]{2}{*}{ Locus } & \multicolumn{2}{|c|}{ Hardy-Weinberg } & \multicolumn{2}{|c|}{ Wright's $F$ statistics } & \multirow[b]{2}{*}{$F_{\text {IT }}$} \\
\hline & $x^{2}$ & df & $F_{\text {IS }}$ & $F_{\mathrm{ST}}$ & \\
\hline Acoh & 1.287 & 2 & -0.069 & 0.017 & -0.050 \\
\hline$F d h$ & $14.873^{*}$ & 1 & -0.122 & $0.075^{*}$ & -0.038 \\
\hline Gcd & 6.210 & 1 & -0.067 & 0.029 & 0.035 \\
\hline G3pdh & 0.126 & 2 & -0.178 & 0.001 & -0.177 \\
\hline Hadh & 0.087 & 1 & 0.243 & 0.001 & $0.244^{*}$ \\
\hline$I d h$ & 2.665 & 2 & -0.036 & 0.014 & -0.022 \\
\hline$M p i$ & 12.139 & 5 & 0.047 & $0.033^{*}$ & 0.078 \\
\hline $\mathrm{Pgm}$ & 9.770 & 3 & 0.124 & $0.052^{*}$ & 0.169 \\
\hline Mean & $47.156^{*}$ & 17 & -0.001 & 0.023 & 0.022 \\
\hline
\end{tabular}

*Significantly different from $0(P<0.01)$. 
Table IV. Hardy-Weinberg Contingency $\chi^{2}$ and Wright's Hierarchical $F$ Statistics for C. hominivorax Populations ${ }^{a}$

\begin{tabular}{|c|c|c|c|c|c|}
\hline \multirow[b]{2}{*}{ Locus } & \multicolumn{2}{|c|}{ Hardy-Weinberg } & \multicolumn{3}{|c|}{$F_{x y}$} \\
\hline & $x^{2}$ & df & Population-country & Country-total & Population-total \\
\hline Acoh & 20.133 & 15 & 0.013 & -0.004 & 0.009 \\
\hline$F d h$ & $37.587^{*}$ & 10 & 0.045 & -0.016 & 0.030 \\
\hline Fumh & 1.962 & 5 & 0.000 & -0.002 & -0.002 \\
\hline$G c d$ & 10.698 & 10 & 0.010 & -0.006 & 0.004 \\
\hline G3pdh & 2.889 & 10 & 0.000 & -0.001 & -0.001 \\
\hline Hadh & $46.259^{*}$ & 10 & 0.005 & 0.012 & 0.018 \\
\hline$I d h$ & 29.424 & 15 & 0.013 & 0.001 & 0.015 \\
\hline$M d h$ & 7.987 & 15 & 0.013 & -0.004 & 0.009 \\
\hline$M p i$ & $85.038^{*}$ & 30 & 0.014 & -0.001 & 0.013 \\
\hline$P g m$ & 29.853 & 15 & 0.032 & -0.009 & 0.023 \\
\hline Pgdh & 1.119 & 5 & 0.002 & -0.001 & 0.001 \\
\hline Combined & $272.948^{*}$ & 140 & 0.013 & -0.001 & 0.012 \\
\hline
\end{tabular}

${ }^{a}$ Countries are Brazil and Costa Rica. Four collections-Bijagua-1 and -2, Emilia, and Montezuma-are considered populations within Costa Rica (Taylor and Peterson, 1994) and two collections-Rio de Janeiro and Rio Grande do Sul-are considered populations within Brazil.

${ }^{*}$ Significantly different from expected $(P<0.01)$.

\section{DISCUSSION}

The level of genetic differentiation observed between NWS populations from Central and South America was low and falls well within the range expected for intraspecific variation (Ayala et al., 1974). Wright's $F$ statistics indicate that more genetic variability exists within and between populations from each country than exists between the countries. This is supported by the cluster analyses which failed to associate the geographically related

Table V. Wright's Hierarchical $F$ Statistics for Three Loci, G3pdh, Fdh $(=O d h)$, and $P g m$ in C. hominivorax Populations from Brazil, Costa Rica (Taylor and Peterson, 1994), and Mexico (Krafsur and Whitten, 1993) ${ }^{a}$

\begin{tabular}{lcccccc}
\hline & \multicolumn{2}{c}{ Hardy-Weinberg } & \multicolumn{3}{c}{$F_{x y}$} \\
\cline { 2 - 3 } \cline { 5 - 6 } \multicolumn{1}{c}{ Locus } & $\chi^{2}$ & $\mathrm{df}$ & & Population-country & Country-total & Population-total \\
\hline Fdh & $229.203^{*}$ & 21 & & 0.064 & 0.008 & 0.072 \\
G3pdh & 11.877 & 14 & 0.002 & 0.003 & 0.005 \\
Pgm & $62.173^{*}$ & 21 & & 0.030 & -0.004 & 0.026 \\
Combined & $303.252^{*}$ & 56 & 0.043 & 0.007 & 0.049 \\
\hline
\end{tabular}

${ }^{a}$ Rio de Jaǹeiro and Rio Grande do Sul were considered populations within Brazil; Bijagua-1 and -2, Emilia, and Montezuma were considered populations within Costa Fica; and Colima and Manzanillo were considered populations within Mexico.

${ }^{*}$ Significantly different from expected $(P<0.01)$. 
Table VI. Nei's Unbiased Genetic Distances for C. hominivorax Populations from Mexico (Krafsur and Whitten, 1993), Costa Rica (Taylor and Peterson, 1994), and Brazil

\begin{tabular}{|c|c|c|c|c|c|c|c|c|}
\hline Location & 1 & 2 & 3 & 4 & 5 & 6 & 7 & 8 \\
\hline \multicolumn{9}{|l|}{ Mexico } \\
\hline 1. Colima & - & $0.000^{a}$ & $0.031^{a}$ & $0.007^{a}$ & $0.010^{a}$ & $0.010^{a}$ & $0.023^{a}$ & $0.003^{a}$ \\
\hline 2. Manzanillo & & - & $0.025^{a}$ & $0.005^{a}$ & $0.006^{a}$ & $0.006^{a}$ & $0.018^{a}$ & $0.002^{a}$ \\
\hline \multicolumn{9}{|l|}{ Costa Rica } \\
\hline 3. Bijagua-1 & & & - & 0.000 & 0.000 & 0.000 & 0.005 & 0.004 \\
\hline 4. Bijagua-2 & & & & - & 0.001 & 0.000 & 0.005 & 0.003 \\
\hline 5. Emilia & & & & & - & 0.000 & 0.002 & 0.003 \\
\hline 6. Montezuma & & & & & & - & 0.004 & 0.001 \\
\hline \multicolumn{9}{|l|}{ Brazil } \\
\hline 7. Rio de Janeiro & & & & & & & - & 0.006 \\
\hline 8. Rio Grande do Sul & & & & & & & & - \\
\hline
\end{tabular}

${ }^{a}$ Based upon three loci, $F d h(=O d h), G 3 p d h(=G p d h)$, and Pgm.

populations. These results, with those of Krafsur and Whitten (1993) and Taylor and Peterson (1994), support the contention that NWS is a single, panmictic species throughout both its historical and its existing ranges. The level of genetic divergence observed among NWS populations from North, Central, and South America is small given the geographical distances.

Taylor and Peterson (1995) obtained similar results for C. macellaria, a blow fly closely related to NWS. They obtained genetic distances of $\leq 0.002$ among C. macellaria populations from North, Central, and South America and attributed the low levels of genetic differentiation to the ephemeral nature of the carrion used for larval development and the need for females to disperse and seek new carrion each generation. Wounds, similar to carrion, also are ephemeral. Under natural conditions, either a wound would heal or the animal would die before a second generation of NWS could complete development. Therefore, the female NWS must disperse in search of new wounds each generation. This process results in a high level of gene flow and prevents genetic differentiation of NWS populations.

These studies indicate that NWS is a genetically homogeneous species throughout its range and that genetic incompatibilities should not pose a problem for the eradication of NWS to the Isthmus of Panama and possibly eventually throughout South America.

\section{ACKNOWLEDGMENTS}

We would like to thank E. Krafsur for providing raw data for screwworms from Mexico, C. Marcelos de Oliveira for screwworms from Rio Grande do Sul, D. Marques Macedo, A. de Souza Leandro, and V. Pereira da Silva 
Junior for assistance in collecting screwworms from Rio de Janeiro, and T. Heller for technical assistance. S. Kamble, J. Petersen, and B. Siegfried provided helpful suggestions and critical reviews of the manuscript. This study was partially funded by Trust Fund Cooperative Agreement No. 58-5440-4-F009 provided by the Food and Agriculture Organization of the United Nations. This work was done in cooperation with the Institute of Agriculture and Natural Resources, University of Nebraska, Lincoln, and is published as Journal Series, Nebraska Agricultural Research Division Paper 10999. The U.S. Department of Agriculture, Agricultural Research Service, Northern Plains Area, is an equal opportunity/affirmative action employer and all agency services are available without discrimination.

\section{REFERENCES}

Ayala, F. J., Tracey, M. L., Hedgecock, D., and Richmond, R. C. (1974). Genetic differentiation during the speciation process in Drosophila. Evolution 28:576.

Dear, J. P. (1985). A revision of the New World Chrysomyini (Diptera: Calliphoridae). Rev. Bras. Zool. 3:109.

Dev, V., LaChance, L. E., and Whitten, C. J. (1986). Polytene chromosomes, karyotype correlations, and population cytology of the primary screwworm fly. J. Hered. 77:427.

Graham, O. H. (1985). Symposium on eradication of the screwworm from the United States and Mexico. Misc. Publ. Entomol. Soc. Am. 62:1.

Guimaraes, J. H., Papavera, N., and do Prado, A. P. (1983). As miiases na regiao neotropical (identifacacao, biologia, bibliografia). Rev. Bras. Zool. 1:239.

Knipling, E. F. (1955). Possibilities of insect control or eradication through the use of sexually sterile males. J. Econ. Entomol. 48:459.

Krafsur, E. S., and Whitten, C. J. (1993). Breeding structure of screwworm fly populations (Diptera: Calliphoridae) in Colima, Mexico. J. Med. Entomol. 30:477.

Krafsur, E. S., Whitten, C. J., and Novy, J. E. (1987). Screwworm eradication in North and Central America. Parasitol. Today 3:131.

LaChance, L. E., Bartlett, A. C., Bram, R. A., Gagne, R. J., Graham, O. H., McInnis, D. O., Whitten, C. J., and Seawright, J. A. (1982). Mating types in screwworm populations? Science 218:1142.

McInnis, D. O. (1983). Chromosomal variation in the screwworm: polymorphism or cryptic species. Am. Nat. 122:840.

McInnis, D. O., Whitten, C. J., Mackley, J. W., Peterson, R. D., II, and Spencer, J. P. (1983). Cytogenetic studies of the screwworm, Cochliomyia hominivorax (Diptera: Calliphoridae) from Chiapas, Mexico. Ann. Entomol. Soc. Am. 76:628.

Murphy, R. W., Sites, J. W., Jr., Buth, D. G., and Haufler, C. H. (1990). Proteins I: Isozyme electrophoresis. In Hillis, D. M., and Moritz, C. (eds.), Molecular Systematics, Sinauer, Sunderland, MA, pp. 45-126.

Nei, M. (1978). Estimation of average heterozygosity and genetic distance from a small number of individuals. Genetics 89:583.

Nomenclature Committee International Union of Biochemistry (1984). Enzyme Nomenclature, Academic, New York.

Richardson, R. H., Ellison, J. R., and Averhoff, W. W. (1982). Autocidal control of screwworms in North America. Science 215:361.

Stehli, F. G., and Webb, S. D. (1985). The Great American Biotic Interchange, Plenum, New York.

Swofford, D. L., and Selander, R. B. (1981). BIOSYS-1: A FORTRAN program for the 
comprehensive analysis of electrophoretic data in population genetics and systematics,

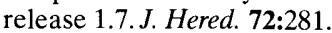

Taylor, D. B., and Peterson, R. D., II (1994). Population genetics and gene variation in primary and secondary screwworm (Diptera: Calliphoridae). Ann. Entomol. Soc. Am. 87:626.

Taylor, D. B., and Peterson, R. D., II (1995). Population genetics and gene variation in secondary screwworm (Diptera: Calliphoridae). Ann. Entomol. Soc. Am. 88:690.

Vargas-Teran, M. (1991). The New World screwworm in Mexico and Central America. World Anim. Rev. Spec. Issue Oct: 28.

Wright, S. (1978). Evolution and the Genetics of Populations, Vol. 4. Variability Within and Among Natural Populations, University of Chicago Press, Chicago. 